\title{
KEEFEKTIFAN MODEL PEMBELAJARAN IMAJINATIF DALAM KETERAMPILAN MENULIS PARAGRAF BAHASA JERMAN SISWA KELAS XII IPA SMA NEGERI 3 MAKASSAR
}

\author{
Susana Indra Jaya ${ }^{1}$ dan Laelah Azizah ${ }^{2}$ \\ Program Studi Pendidikan Bahasa Jerman, Fakultas Bahasa dan Sastra \\ Universitas Negeri Makassar
}

Email: susana.indra@yahoo.com ${ }^{1}$

\begin{abstract}
ABSTRAK
Penelitian ini dilakukan untuk memperoleh data dan informasi tentang keterampilan menulis bahasa Jerman Siswa. Jenis penelitian ini adalah Quasi-eksperimen (non-equivalent design)) Populasi penelitian yaitu seluruh siswa kelas XII IPA SMA Negeri 3 Makassar yang terdiri dari 7 kelas yang berjumlah 320 siswa. Data penelitian ini diperoleh dengan tes keterampilan menulis paragraf bahasa Jerman siswa. Kemudian data dianalisis menggunakan uji-t yang menunjukkan bahwa $t_{\text {hitung }} 7,70>t_{\text {tabel }} 1,998$ dengan taraf signifikan 0,05 . Hasil penelitian ini menunjukkan bahwa penggunaan model pembelajaran imajinatif efektif dalam keterampilan menulis paragraf bahasa Jerman Siswa Kelas XII IPA SMA Negeri 3 Makassar.
\end{abstract}

Kata Kunci: Model Pembelajaran Imajinatif, Keterampilan Menulis, Bahasa Jerman

\begin{abstract}
This study was conducted to obtain data and information about the students' writing skills. This research type is Quasi-experiment (non-equivalent design)) The research population is all students of class XII IPA SMA Negeri 3 Makassar consisting of 7 classes amounting to 320 students. The data of this study were obtained by the students' writing skill test writing German language. Then the data were analyzed using t-test which showed that t-count 7,70> t-table 1,998 with significant level 0,05. The results of this study indicate that the use of imaginative learning model effective in the skill of writing German paragraphs of Class XII Students IPA SMA Negeri 3 Makassar
\end{abstract}

Keywords: Imaginative Learning Model, Writing Skill, German Language

\section{PENDAHULUAN}

Pengajaran bahasa Jerman sebagai salah satu bahasa asing yang diajarkan di Sekolah Menengah Pertama (SMA) atau sederajat yang mengajarkan tentang empat keterampilan yaitu kemampuan menyimak (hören), keterampilan berbicara (sprechen), kemampuan membaca (lesen) dan keterampilan menulis (schreiben).
Berdasarkan keempat keterampilan berbahasa di atas, keterampilan menulis menjadi salah satu keterampilan berbahasa yang sangat penting. Dengan adanya keterampilan menulis, diharapkan siswa mampu mengungkapkan ide, gagasan, atau perasaannya melalui sebuah tulisan. Meski keterampilan menulis menjadi salah satu aspek yang sangat penting, namun 
dalam realitanya kemampuan menulis siswa di Indonesia masih sangat lemah. Hal ini berdasarkan riset yang dilakukan oleh Programme For International Student Assement (PISA) pada tahun 2012 kemampuan menulis siswa di Indonesia sangat lemah. Indonesia menempati posisi ke-65 dari 66 negara anggota PISA (Said dan Budimanjaya, 2015: 77)

Berdasarkan hasil wawancara peneliti dengan pengajar bahasa Jerman di SMAN 3 Makassar diperoleh informasi bahwa keterampilan menulis bagi siswa sangatlah sulit, dikarenakan penguasaan struktur dan kosa kata bahasa Jerman yang kurang serta penggunaan metode yang tidak tepat. Hal tersebut sesuai dengan beberapa hasil penelitian (Mantasiah, 2017; Qalbi, 2017). Hal tersbeut juga diperkuat dengan adanya data pada tahun ajaran 2015/2016 yang menunjukkan bahwa pada aspek keterampilan menulis di kelas XII IPA 6 SMA Negeri 3 Makassar hanya 7 dari 37 siswa yang memperoleh nilai di atas Kriteria Ketuntasan Minimal (KKM ). Data ini menunjukkan bahwa keterampilan menulis bahasa Jerman siswa sangat rendah yaitu dengan persensate $18,91 \%$.

Selain itu, berdasarkan penelitian yang dilakukan oleh Mulyanda (2014) yang menunjukkan bahwa kemampuan menulis narasi berdasaran teks dialog siswa kelas XII IPA SMA Negeri I Bajeng Kabupaten Gowa tergolong rendah yaitu 49,60\%. Selanjutnya Warda (2013) menyatakan keterampilan menulis karangan bahasa Jerman siswa kelas XI SMAN 3 Sungguminasa Kabupaten Gowa berada pada ketegori rendah yaitu 58, $42 \%$.

Berdasarkan masalah tersebut peneliti berpendapat perlu adanya perbaikan proses pembelajaran dengan metode yang menarik. Hal ini dilakukan dengan tujuan agar peserta didik bisa ikut berperan aktif dan lebih tertarik mempelajari bahasa Jerman. Salah satu model pembelajaran yang menarik adalah model pembelajaran imajinatif. Model pembelajaran imajinatif yaitu model pembelajaran dimana siswa diajarkan menguasai kompetensi menulis secara bebas sesuai imajinasinya sendiri-sendiri. Siswa diberi kebebasan untuk menuangkan segala ide/ gagasan, pendapat/opini, imajinasi atau daya khayal, dan sebagainya ke dalam bentuk tulisan.

Penggunaan model pembelajaran imajinatif diharapkan mampu membantu siswa untuk mencapai beberapa indikator yang sesuai dengan silabi pembelajaran bahasa Jerman SMA yang digunakan dalam keterampilan menulis bahasa Jerman. Adapun indikator yang dimaksudkan adalah siswa mampu menulis dan menyusun kata menjadi kalimat serta mampu menyusun kalimat menjadi sebuah paragraf. Selain itu penggunaan model pembelajaran imajinatif ini diharapkan membantu siswa menguasai kosa kata dan tata bahasa Jerman dengan baik.

Meskipun penggunaan model pembelajaran imajinatif masih jarang digunakan terutama dalam mata pelajaran bahasa Jerman, namun model pembelajaran ini pernah digunakan oleh Wulandari (2013) dalam penelitiannya di jurusan pendidikan bahasa Indonesia di SMAN Binjai, Sumatera Utara. Hasil penelitiannya menunjukkan bahwa keefektifan model pembelajaran imajinatif dalam menulis karangan siswa kelas X SMAN Sinjai berada pada kategori baik yaitu sebesar $73,12 \%$. 


\section{PEMBELAJARAN IMAJINATIF}

Guru sebagai pengajar harus mampu memilih model pembelajaran yang cocok dan menarik dengan tujuan agar peserta didik bisa ikut berperan aktif dan lebih tertarik dalam mengikuti pelajaran (Jufri, 2017; Jufri 2007; Qudus, 2017; Romadloni, 2017). Salah satu model pembelajaran yang bisa digunakan guru adalah adalah model pembelajaran imajinatif. Model ini mengajarkan siswa untuk mengarang secara bebas berdasarkan imajinasinya masingmasing. Siswanto dan Ariani (2016) menjelaskan bahwa model pembelajaran dimana siswa diberi kebebasan untuk menuangkan segala ide atau gagasan, pendapat atau opini, imajinasi atau daya khayalnya ke dalam bentuk tulisan.

Menurut Said dan Budimanjaya (201

5 : 77) menulis imajinatif adalah kemampuan memberikan gambaran melalui rangkaian tulisan yang bersumber dari daya khayal. Selain itu, Silberman ( 2019) menjelaskan b ahwa model pembelajaran imajinatif adalah model pembelajaran yang dirancang untuk membantu siswa mendapatkan pengetahuan, keterampilan dan sikap secara lebih aktif.

Rafiq (2015:38) menjelaskan bahwa model pembelajaran imajinatif adalah model pembelajaran yang membuat kemampuan belajar menjadi lebih optimal. Berdasarkan beberapa pendapat di atas dapat disimpulkan bahwa model pembelajaran imajinatif adalah model pembelajaran yang mengajak peserta didik untuk menuangkan segala ide atau gagasan, pendapat atau opini, imajinasi atau daya khayal ke dalam bentuk tulisan.

Berikut ini merupakan langkahlangkah model pembelajaran imajinatif menurut Siswanto dan Ariani (2016:34-35) yang kesimpulannya adalah sebagai berikut:
1. Guru memberi penjelasan tentang tujuan pembelajaran atau Kompetensi Dasar.

2. Guru menjelaskan secara singkat cara membuat sebuah tulisan, terutama bentuk menulis cerita bebas.

3. Guru kemudian membagi kertas kerja sesuai dengan jumlah siswa.

4. Setiap siswa membuat tulisan dengan daya cipta dan kreasinya sendiri

5. Setelah selesai, guru menunjuk salah satu siswa untuk menampilkan atau membaca hasil tulisannya.

6. Setiap siswa yang sudah membacakan atau membaca tulisannya diberi aplaus. Siswa yang lain diberi kesempatan untuk menyampaikan kritik, saran atau pendapat berdasarkan tulisan temannya.

7. Guru menunjuk siswa yang lain untuk menampilkan atau membaca tulisannya

8. Evaluasi, meliputi isi tulisan, kalimat, pilihan kata, tanda baca, pengguanaan ejaan, dan sebagainya.

9. Kesimpulan.

Siswanto dan Ariani (2016:33) menjelaskan beberapa kelebihan dan kekurangan model pembelajaran imajinatif antara lain:

1. Kelebihan model pembelajaran imajinatif meliputi 1) memberikan kebebasan kepada siswa untuk menuliskan segala ide yang ada dalam pikirannya tanpa ada batasan-batasan yang membatasi pikiran siswa, 2) membuat siswa lebih kreatif dengan dunia mereka masing-masing, 3) siswa lebih bebas berkreasi dengan dunia mereka masing-masing.

2. Kekurangan model pembelajaran imajinatif meliputi 1) siswa yang kesulitan untuk membangkitkan imajinasi bisa tertinggal dari teman-temannya, 2) penerapan model pembelajaran imajinatif membutuhkan waktu yang agak lama. 
Selain itu, Silberman (2009:13 -14) mengungkapkan bahwa model pembelajaran imajinatif 1) menjadikan siswa aktif sejak awal, 2) membantu siswa lebih mengenal satu sama lain atau menciptakan semangat kerja antar siswa, 3) membantu proses belajar secara langsung sehingga menimbulkan minat awal terhadap pelajaran 4) menjadikan siswa kreatif, 5) membantu siswa mendapatkan pengetahuan, keterampilan, dan sikap secara aktif.

Selain itu, kelemahan dari model pembelajaran imajinatif menurut Silberman (2009) adalah 1) banyak waktu yang diperlukan dalam penggunaan model pembelajaran ini, 2) model pembelajaran imajinatif hanya menjadi kumpulan kegembiraan dan permainan sehingga siswa kadang-kadang kurang serius.

\section{METODE PENELITIAN}

Desain penelitian yang digunakan dalam penelitian ini adalah Quasi Eksperimental Design model Nonequivalent Control Group Design. Kedua kelas (kelas eksperimen dan kelas kontrol) diberi tes awal (pre-test) dengan tujuan untuk mengetahui kemampuan awal siswa sebelum diberikan perlakuan (treatment). Kelas eksperimen diberi perlakuan khusus yaitu dengan menerapkan model pembelajaran imajinatif sedangkan pada kelas kontrol tidak diberi perlakuan khusus dan siswa hanya menulis paragraf. Setelah itu kedua kelas diberikan tes akhir (post-test).

Keterampilan menulis paragraf bahasa Jerman yang dimaksud dalam penelitian ini adalah kemampuan siswa menulis kalimat/sejumlah kalimat yang saling berhubungan antara yang satu dengan yang lainnya sehingga membentuk paragraf bahasa Jerman dengan memperhatikan kesesuaian isi paragraf dengan tema, pemilihan kata (diksi), penggunaan ejaan dan tanda baca, kohesi dan koherensi, dan imajinasi berdasarkan tema die Freizeit.

Populasi dalam penelitian ini adalah seluruh siswa kelas XII IPA SMA Negeri 3 Makassar yang berjumlah 7 kelas dengan jumlah keseluruhan siswa 320 siswa. Sampel dalam penelitian ini yaitu kelas IPA 7 SMAN 3 Makassar yang berjumlah 34 orang sebagai kelas eksperimen dan kelas IPA 3 yang berjumlah 34 orang sebagai kelas kontrol sehingga total sampel berjumlah 68 siswa. Teknik yang digunakan dalam pengambilan sampel dalam penelitian ini adalah random sampling.

Teknik pengumpulan data yang digunakan dalam penelitian ini adalah dengan menggunakan instrumen berupa tes kemampuan menulis paragraf bahasa Jerman.Teknik analisis data dalam penelitian ini adalah teknik analisi inferensial. Untuk menguji hipotesis penelitian dilakukan dengan dengan menggunakan uji-t. Sebelum melakukan pengujian tersebut terlebih dahulu dilakukan uji normalitas dengan menggunakan tabel Z-score dan chi kuadrat, Akan tetapi sebelum menentukan uji normalitas data dan homogenitas maupun uji hipotesis terlebih dahulu tentukan nilai rata-rata (mean), simpangan baku dan varian.

\section{HASIL DAN PEMBAHASAN}

Pada bagian ini dibahas tentang hasil yang diperoleh dari analisis data penelitian tentang keefektifan model pembelajaran imajinatif dalam keterampilan menulis paragraf bahasa Jerman siswa kelas XII IPA SMA Negeri 3 Makassar. Pembelajaran pada penelitian ini dilakukan selama 4 kali pertemuan. setelah pemberian pre-test kedua 
kelas kemudian diajarkan menggunakan model pembelajaran yang berbeda. Pada kelas eksperimen siswa diajarkan menggunakan model pembelajaran imajinatif sedangkan pada kelas kontrol siswa tidak diajarkan dengan model pembelajaran imajinatif, dalam hal ini menggunakan metode tanya jawab dan diskusi.

Penelitian ini merupakan penelitian quasi eksperimental design model nonequivalent control group design. Populasi dalam penelitian adalah seluruh siswa kelas XII IPA SMA Negeri 3 Makassar yang berjumlah 320 siswa sedangkan sampel penelitian adalah kelas XII IPA 3 dan kelas XII IPA 7 yang dipilih secara acak (random sampling) yang berjumlah 68 siswa. Hasil pre-test menunjukkan bahwa nilai rata-rata (mean) untuk kelas eksperimen (XII IPA 7) adalah 46,11 dan kelas kontrol (XII IPA3) adalah 32,32 dalam keterampilan menulis paragraf bahasa Jerman siswa kelas XII IPA SMA Negeri 3 Makassar, jumlah skor perolehan untuk kelas eksperimen adalah 1568 dan kelas kontrol adalah 1099.

Berdasarkan nilai yang diperoleh siswa dapat diketahui bahwa semua nilai pretest siswa dari kedua kelas sampel sangatlah rendah. Hal ini disebabkan oleh rendahnya pengetahuan awal siswa terhadap materi yang akan diajarkan. Hasil uji normalitas pada data pre-test menunjukkan bahwa hasil pada kedua kelas eksperimen dan kontrol memiliki chi-kuadrat hitung masing-masing lebih kecil dari chi-kuadrat tabel, $\chi_{\text {hitung }}$ $<\chi_{\text {tabel}}$, dimana pre-test kelas eksperimen ($138,77<11,07)$ dan pre- test kelas kontrol ($143,98<11,07)$, sehingga distribusi data pretest dinyatakan normal, artinya tes yang diberikan sesuai dengan kemampuan siswa. Setelah uji normalitas langkah selanjutnya adalah menetukan uji homogenitas dan hasilnya adalah kedua sampel adalah homogen dimana $F_{\text {hitung }} 2,28<\mathrm{F}_{\text {tabel }} 5,050$.

Penelitian ini dilakukan untuk mengetahui keefektifan penggunaan model pembelajaran imajinatif dalam keterampilan menulis paragraf bahasa Jerman siswa kelas XII IPA SMA Negeri 3 Makassar. Keefektifan model pembelajaran imajinatif ini ditunjukkan dengan adanya perubahan pada nilai rata-rata hasil belajar siswa pada tes akhir pada kelas eksperimen serta terdapat perbedaan hasil belajar yang si gnifikan antara kelas yang menggunakan model pembelajaran imajinatif (kelas eksperimen) dan model pembelajaran konvensional (kelas kontrol).

Berdasarkan hasil post-test kelas eksperimen, penggunaan model pembelajaran imajinatif berdampak positif pada peningkatan keterampilan menulis paragraf bahasa Jerman siswa. Hal tersebut dapat dilihat dari perolehan nilai post-test siswa, pada kelas eksperimen dimana nilai terendah siswa yaitu 34 dan nilai tertinggi 88 dengan nilai rata-rata 63,32 sedangkan pada kelas kontrol diperoleh nilai 29 untuk nilai terendah dan 71 untuk nilai tertinggi dengan nilai rata-rata 43,14.

Hasil analisis di atas, dilanjutkan dengan uji-t untuk melihat hasil akhir dari penelitian ini. Hasilnya adalah $t$ hitung= 7,70 sementara $t$ tabel $=1,998$ jadi $t$ hitung $\geq t$ tabel $(7,70) \geq 1,998)$. Dengan demikian, $\mathrm{H}_{1}$ yang menyatakan bahwa ada perbedaan keefektifan yang signifikan antara antara keterampilan menulis paragraf bahasa Jerman siswa yang diajar dengan menggunakan model pembelajaran imajinatif dan siswa yang tidak diajar dengan menggunakan model pembelajaran imajinatif siswa kelas XII IPA SMA Negeri 3 Makassar dinyatakan diterima dan $\mathrm{H}_{0}$ yang menyatakan 
bahwa tidak ada perbedaan keefektifan yang signifikan antara keterampilan menulis paragraf bahasa Jerman siswa yang diajar dengan menggunakan model pembelajaran imajinatif dan siswa yang tidak diajar dengan menggunakan model pembelajaran imajinatif kelas XII IPA SMA Negeri 3 Makassar ditolak. Oleh karena itu, dapat disimpulkan bahwa penelitian tentang keefektifan penggunaan model pembelajaran imajinatif dalam keterampilan menulis paragraf bahasa Jerman siswa kelas XII IPA SMA Negeri 3 Makassar dinyatakan berhasil.

Nilai siswa pada tes akhir (post-test) menunjukkan bahwa tingkat kemampuan dan pemahaman siswa kelas eksperimen lebih baik daripada siswa kelas kontrol setelah digunakannya masing-masing model pembelajaran, dalam hal ini model pembelajaran imajinatif pada kelas eksperimen dan model pembelajaran konvensional pada kelas kontrol. Meskipun tidak semua nilai post-test siswa kelas eksperimen mencapai kriteria ketuntasan minimal (KKM), namun peningkatan hasil belajar siswa dapat diketahui bahwa semakin besar interval selisih nilai dan peningkatan hasil belajar yang diperoleh siswa. Hal ini disebabkan oleh perbedaan tingkat penguasaan materi siswa pada materi die Freizeit yang telah diajarkan setelah diterapkannya model pembelajaran yang berbeda pada kedua kelas sampel yaitu model pembelajaran imajinatif dan model pembelajaran konvensional. Jadi, dapat disimpulkan bahwa pada kedua kelas sampel yang berbeda, peningkatan hasil belajar siswa pada penerapan model pembelajaran imajinatif lebih baik dari pada peningkatan hasil belajar siswa setelah penggunaan model pembelajaran konvensional.
Pada kelas kontrol susasana pembelajaran tidak sehidup pada kelas eksperimen. Hal ini disebabkan karena siswa diajarkan menggunakan model pembelajaran konvensional. Model pembelajaran kovensional atau model pembelajaran yang biasa dilakukan oleh guru, kurang menarik minat siswa dan kurang memotivasi siswa. Selain itu, siswa tidak terlalu semangat dalam mengikuti pembelajaran yang berlangsung serta kurang semangat dan antusias dalam belajar, rasa keingintahuan yang dimiliki kurang sehingga mengakibatkan suasana kelas menjadi pasif dan berdampak pada rendahnya nilai siswa dan prestasi belajarnya yang rendah. Dengan model pembelajaran konvensional ini siswa hanya mengandalkan informasi dari guru saja.

Sedangkan pada kelas eksperimen siswa diajarkan menggunakan model pembelajaran imajinatif. Model pembelajaran imajinatif pada awal pembelajaran dilakukan dengan membangunan kepercayaan diri siswa, hal ini sangat penting karena dengan kepercayaan diri yang tinggi, siswa cenderung akan berhasil walau bagaimana pun kemampuan yang dimilikinya. Hal ini untuk mendorong mereka agar berusaha memanfaatkan kemampuannya secara maksimal dan sungguh-sungguh sehingga keberhasilan yang optimal dapat tercapai dalam hal ini keberhasilan pembelajaran. Dengan sikap yakin, penuh percaya diri dan merasa mampu dapat melakukan sesuatu dengan berhasil, siswa terdorong untuk melakukan sesuatu kegiatan dengan sebaik-baiknya sehingga dapat mencapai hasil yang lebih baik dari sebelumnya atau dapat melebihi orang lain. Keberhasilan pembelajaran siswa juga didukung oleh minat dan ketertarikan siswa untuk belajar. Dalam proses belajar 
mengajar pada kelas eksperimen siswa dituntut untuk aktif misalnya siswa diberi kesempatan bertanya dan menyampaikan pendapatnya secara bebas dan saling berkompetisi sehingga suasana kelas lebih hidup.

Hasil pengamatan yang peneliti peroleh selama proses penelitian adalah siswa menyukai model pembelajaran imajinatif karena siswa merasa model pembelajaran ini merupakan model pembelajaran yang baru sehingga membuat siswa tertarik, menyenangkan dan lebih mudah memahami materi dan dapat meningkatkan pemahaman siswa. Dari hasil penelitian dapat dilihat bahwa model pembelajaran imajinatif memiliki pengaruh besar terhadap keterampilan menulis paragraf bahasa Jerman siswa kelas XII IPA SMA Negeri 3 Makassar.

\begin{tabular}{lll}
\multicolumn{1}{c}{ Hasil } & \multicolumn{1}{c}{ penelitian yang telah } \\
didapatkan & mendukung & \multicolumn{1}{c}{ teori yang } \\
dikemukakan & oleh Silberman & $(2019: 12)$
\end{tabular}
yang menjelaskan bahwa "model pembelajaran imajinatif adalah model pembelajaran yang dirancang untuk membantu siswa untuk mendapatkan pengetahuan serta keterampilan secara lebih aktif'. Teori lain yang mendukung pernyataan dari Silberman adalah teori yang dikemukakan oleh Rafiq (2015:38) yang menjelaskan bahwa dengan diterapkannya model imajinatif dalam pembelajaran maka kemampuan belajar siswa menjadi optimal.

\section{KESIMPULAN}

Berdasarkan hasil penelitian yang telah dijelaskan pada bagian sebelumnya, dapat disimpulkan bahwa model pembelajaran imajinatif efektif dalam keterampilan menulis paragraf bahasa Jerman siswa kelas XII IPA SMA Negeri 3 Makassar. Hal tersebut dibuktikan melalui hasil pengujian hipotesis dengan menggunkan uji t terhadap nilai post-test siswa. Adapun hasilnya adalah $t_{\text {hitung }}=7,70>t_{\text {tabel }}=1,998$ pada taraf signifikan 0,05 .

\section{DAFTAR PUSTAKA}

Jufri, J. 2007. Metode Penelitian Bahasa. Sastra dan Budaya.

Jufri, J., 2017. Strategi Pembelajaran Bahasa.

Mantasiah, R., Juffri, J., \& Yusri, Y. 2017.

Keefektifan Model Pembelajaran Jaring

Laba-Laba (Webbed) dalam

Keterampilan Menulis Karangan

Sederhana Bahasa Jerman. INSANI, 20(2).

Mulyanda, dian. 2014. Kemampuan Menulis

Narasi Bahasa Jerman Berdasarkan

Teks Dialog Siswa Kelas XII IPA SMA Negeri 1 Bajeng Kabupaten Gowa. Makassar. Skripsi. FBS UNM.

Qalbi, U. N., Mantasiah, R., Jufri, J., \& Yusri, Y. 2017. Efektivitas Model Pembelajaran Kooperatif Tipe Teams Games Tournaments dalam Keterampilan Menulis Bahasa Jerman Siswa Kelas XII IPA SMA Negeri 1 Bontonompo Kabupaten Gowa. INSANI, 20(1).

Qudus, M. and Yusri, Y., 2017. Keefektifan Penggunaan Metode Audio Lingual dalam Pembelajaran Kemampuan Menyimak Bahasa Jerman. INSANI, 20(2).

Romadloni, A., \& Mantasiah, R. Intercultural approach in foreign language learning to improve students' motivation. Senior Editors, 61.

Silberman. 2009. Active Learning, 101 Cara Belajar Siswa Aktif. Bandung: Nuansa dan Nusa Media. 
Siswanto, Wahyudi dan Ariani, Dewi. 2016. Model Pembelajaran Menulis Cerita. Bandung : PT Rafika Aditama

Warda. 2013. Keterampilan Menulis Karangan Sederhana Bahasa Jerman Siswa Kelas XI SMAN 3 Kabupaten Gowa. Makassar. Skripsi. FBS UNM.

Wulandari, Meirini. 2013. Pengaruh penggunaan Strategi pembelajaran imajinasi terhadap kemampuan menulis paragraf narasi sugestif siswa kelas $\mathrm{X}$ SMA Negeri 5 Sinjai. Skripsi. Universitas Negeri Makassar

Yusri, Y., Mantasiah, R., \& Jufri, J. 2018. The Use Of Two Stay Two Stray Model in English Teaching to Increase Student's Learning Outcome. Journal of Advanced English Studies, 1(1), 39-43. 